\title{
COMBINATION OF MOVING BED BIOFILTER AND ACTIVATED SLUDGE PROCESS TO REMOVE ORGANIC LOADING FROM SEAFOOD WASTEWATER
}

\author{
Do Van Manh ${ }^{1,2, ~ *, ~ T r u o n g ~ T h i ~ H o a ~}{ }^{1}$, Nguyen Viet Thoan ${ }^{1}$, Do Tuan Anh ${ }^{1}$, \\ Nguyen Tuan Minh ${ }^{2}$, Le Minh Tuan ${ }^{2}$ \\ ${ }^{I}$ Da Nang Environmental Technology Center, Tran Dai Nghia, Ngu Hanh Son, Da Nang \\ ${ }^{2}$ Institute of Environmental Technology, Vietnam Academy of Science and Technology, \\ 18 Hoang Quoc Viet, Cau Giay, Ha Noi \\ *Email: dovanmanh@yahoo.com
}

Received: 10 May 2016; Accepted for publication: 30 September 2017

\begin{abstract}
The combination between moving bed biofilter (MBF) and conventional activated sludge (CAS) process was conducted to treat seafood processing wastewater with high organic concentration in Ha Long canned food factory. The high automatic operation of pilot was designed with treatment volume of $2 \mathrm{~m}^{3} / \mathrm{day}$. The capacity of organic removal loading was investigated in the range of $1 ; 1.5 ; 2 ; 2.5$ and $5 \mathrm{~kg} \mathrm{BOD}{ }_{5} / \mathrm{m}^{3} . \mathrm{d}$, respectively. The obtained results indicate that the organic $\left(\mathrm{BOD}_{5}\right)$ removal efficiencies of the studied pilot and the two-stagesactivated sludge being used in the factory are $90-95 \%$ and $45-50 \%$, respectively as at the same organic loading. This highly application study, therefore, suggests that the combination of moving bed biofilter with conventional activated sludge process tends to be a promising technology for wastewater treatment of seafood processing industry in Vietnam.
\end{abstract}

Keywords: moving bed biofilter, seafood processing wastewater treatment, activated sludge.

\section{INTRODUCTION}

The sea food processing industry (SFPI) thrives in countries with large surface water. The preliminary processing and processing activities generate a large amount of wastewater (catfish: $5-7 \mathrm{~m}^{3} /$ tone, frozen shrimp: $4-6 \mathrm{~m}^{3} /$ tone, and surimi: $20-25 \mathrm{~m}^{3} /$ tone; and mixed frozen seafood: $4-6 \mathrm{~m}^{3} /$ tone) with unstable flow based on seafood seasonality and the various types of processed products. The components of the pollutants are mainly decomposable organic substances in small suspended particles (TSS), dispersed and colloidal matters (BOD and COD), and nutrients $(\mathrm{N}, \mathrm{P})$. The seafood wastewater without adequate treatment and control methods will cause pollution to coastal waters as receiver sources as well as odor pollution due to the decomposition of organic matters $[1,2]$. The impact of the seafood processing industry on the environment depends not only on the type of processing but also on other factors such as production scales, products, input materials, seasonalities, production technology, level of organization and management of production, etc. in which the engineering, technician, and production management factors have a decisive influence on the environmental protection of each enterprises. 
Some of the typical environmental impacts of the seafood processing industry are listed as: (1) Air pollution: odors arising from storage area of solid wastes residual during the production process, emissions from the boiler burning and generators; (2) Solid wastes: arising from processing includes shellfish, cuttlefish, squid and fish, etc.; (3) Wastewater: the amount of production wastewater in fishery processing is about $85-90 \%$ of total amounts of wastewater, mainly from the processes of washing raw material, processing, finishing, washing equipment, tools, and processing areas [3, 4]. Based on the results of numerous studies during past time, the US Environmental Protection Agency (US EPA) has issued regulations and recommendations for the use of treatment technologies in terms of the minimization of the amount of water used in processing and controlling the effluents. The suggested seafood processing wastewater treatment method is as following: (1) pre-treatment: removal of large matters; (2) preliminary treatment (Level I) with processes: (i) mechanical (filtration, settling) combined with physicochemical processes (coagulation and flocculation) or (ii) mechanical and anaerobic biochemistry to reduce the concentration of TSS and organic compounds; (3) biological treatment (Level II): aerobic biochemistry to eliminate the organic and nutrient components; and (4) final treatment (Level III): aerobic biochemistry, rapid gravity filtration, wetland or biological lakes for completely removal of organic and nutrient substances [2].

In fact, seafood wastewater treatment of small processing scale and oscillated concentration and loading is still obstacle now, due to the mechanical processes could not remove the amount of entire existed organic contents in wastewater such as fats, oils and greases [1]. In order to reduce the burden to treatment processes and enhancing removal capacity of organic contaminant as well as the biochemical inhibitors, the flotation technique has been applied after mechanical, physical and chemical treatments since the 1990s. This technique has been recommended by FAO as an effective method to eliminate the fats, oils and greases prior to the application of aerobic processes $[1,5,6]$. In the last 20 years, Vietnam has always been in the top 10 of the seafood export countries. Along with positive export achievements, Vietnam is currently facing serious environmental problems releasing from seafood processing activity. The major barriers of seafood wastewater treatment in Vietnam now are lack of proper investment policies, application of adequate technologies and appropriate operation. Hence, finding out the technique with high treatment efficiency, simple operation and low cost is an urgent requirement now.

\section{EXPERIMENTAL}

\subsection{Wastewater samples}

Table 1. The specific concentration wastewater of Ha Long can food factory.

\begin{tabular}{clc}
\hline No & Parameter & Specific value \\
\hline 1 & $\mathrm{pH}$ & $6-8$ \\
2 & $\mathrm{COD}, \mathrm{mg} / \mathrm{l}$ & $2500-6000$ \\
3 & BOD $_{5}, \mathrm{mg} / \mathrm{l}$ & $1500-3200$ \\
4 & $\mathrm{TSS}, \mathrm{mg} / \mathrm{l}$ & $1200-1500$ \\
5 & $\mathrm{~T}-\mathrm{N}, \mathrm{mg} / \mathrm{l}$ & $300-350$ \\
6 & $\mathrm{~T}-\mathrm{P}, \mathrm{mg} / \mathrm{l}$ & $30-50$ \\
7 & $\mathrm{~T}-\mathrm{oil}, \mathrm{mg} / \mathrm{l}$ & $150-200$ \\
\hline
\end{tabular}


The studied wastewater samples were collected from the equalization tank of Ha Long wastewater treatment plant (WWTP), which is located in Danang seafood service industrial zone, Danang, Vietnam. This factory processes the tuna can so that the wastewater (WW) content is of high contamination, whose specific concentration was tested and indicated in Table 1.

\subsection{Experimental set-up}

The experimental pilot was designed with treatment capacity of $2 \mathrm{~m}^{3} /$ day, which is located next to the existed Ha Long WWTP. This compact system was manufactured and equipped by Hiyoshi Company, Shiga Prefecture, Japan. The Kuraray PVA gel was supplied by Kuraray Company, Osaka, Japan. The scheme diagram is shown in Fig. 1.

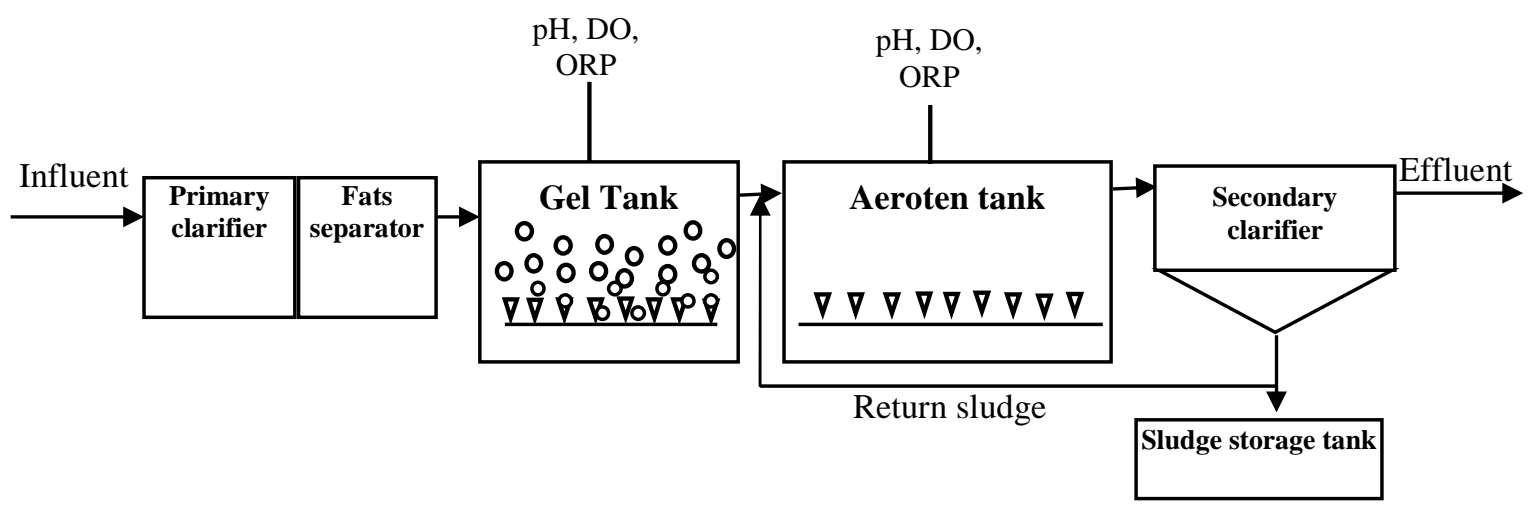

Figure 1. Scheme diagram of moving bed biofilter and conventional activated sludge.

The WW is pumped from the existed plant's equalization tank, passed through the primary filter, and then transferred to the oil separator. From the oil separator, the WW was continued pumping into the Gel tank, where biofilter material as the polyvinyl alcohol (PVA) was filled in $20 \%$ volume. The specification of PVA particles is manufactured diameter of $0.4 \mathrm{~mm}$ and porous size less than $20 \mu \mathrm{m}$ (Fig. 2). Entire of $\mathrm{pH}$, DO, ORP, water level, and system operation were controlled by sensors and camera.

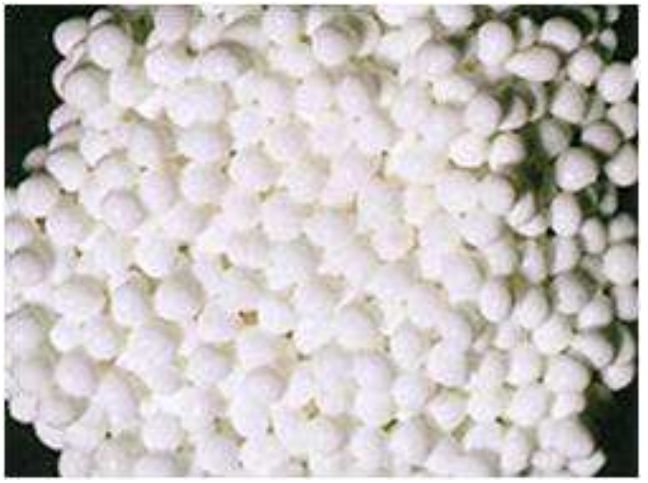

PVA particles

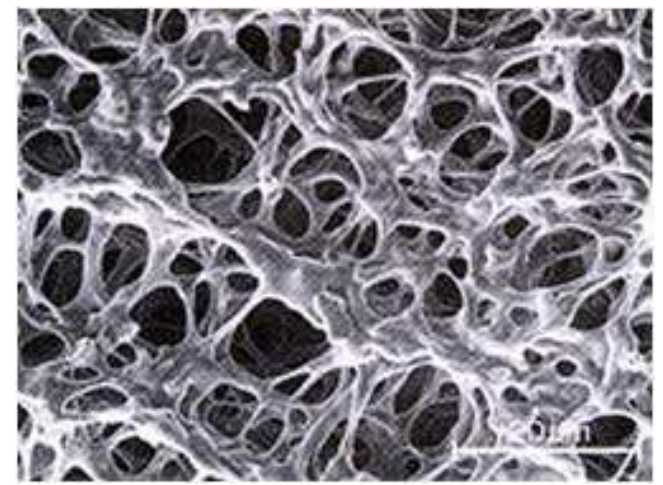

Porous size $<20 \mu \mathrm{m}$

Figure 2. PVA particles and pore size. 
The WW was further transferred to the aeroten tank, where the remained organic component is continually eliminated. Mixed liquor suspended solids (MLSS) in the aeroten tank was kept about $2000 \mathrm{mg} / \mathrm{L}$. Finally, the WW was transferred to the secondary clarifier tank, here activated sludge. (AS) was partly returned to the aeroten tank to maintain the microorganism density of the system.

The whole system was fully automated and controlled by a programmable logic controller (PLC) device and monitored by a direct camera. All problems were timely controlled in an effective manner to enhance the reliability of experimental results.

The operational parameters and experimental conditions in the work were shown in Table 2. Each experimental mode was controlled in the interval of 30 days and the total experimental period lasted for 5 months.

Table 2. Experimental conditions.

\begin{tabular}{|c|c|c|c|c|c|c|c|}
\hline \multicolumn{2}{|c|}{ No. Parameters } & \multicolumn{6}{|c|}{ Experimental conditions } \\
\hline 1 & Loading capacity & $\mathrm{m}^{3} / \mathrm{d}$ & 0.8 & 1.2 & 1.6 & 2 & 4 \\
\hline 2 & BOD (influent) & $\mathrm{mg} / \mathrm{L}$ & \multicolumn{5}{|c|}{ 2000-3000 } \\
\hline 3 & BOD loading rate (input) & $\mathrm{kg} / \mathrm{d}$ & 2 & 3 & 4 & 5 & 10 \\
\hline 4 & Volume (Gel tank) & $\mathrm{m}^{3}$ & 2 & 2 & 2 & 2 & 2 \\
\hline 5 & BOD loading (Gel tank) & $\mathrm{kg} / \mathrm{m}^{3} / \mathrm{d}$ & 1 & 1.5 & 2 & 2.5 & 5 \\
\hline 6 & BOD loading (Aeroten tank) & $\mathrm{kg} / \mathrm{d}$ & 0.5 & 0.75 & 1 & 1.25 & 2.5 \\
\hline 7 & $\mathrm{pH}$ (Gel and Aeroten tanks) & & 7.5 & 7.5 & 7.5 & 7.5 & 7.5 \\
\hline 8 & DO (Gel và Aeroten tank) & $\mathrm{mg} / \mathrm{L}$ & $4.5-5$ & $4.5-5$ & $4.5-5$ & $4.5-5$ & $4.5-5$ \\
\hline 9 & Sampling site & & \multicolumn{5}{|c|}{$\begin{array}{l}\text { After fats separator, Gel tank and secondary } \\
\text { clarifier tank }\end{array}$} \\
\hline 10 & Evaluation parameter & & $\mathrm{BOD}_{5}$ & & & & \\
\hline
\end{tabular}

\subsection{Analysis method}

The collected WW samples were kept in cold boxes, transferred to laboratory, and then stored at $4{ }^{\circ} \mathrm{C}$ in the refrigerator. $\mathrm{BOD}_{5}$ was determined by dilution and allylthiourea implantation according to TCVN 6001-1:2008, and then incubated in BOD cabinet (FOC225I, Velp, Italy) for 5 days.

\subsection{Statistical analysis}

Entire of results in this work were expressed as the average of triplicate experiments. Data in tables and figures were present as mean \pm standard deviation via Microsoft Office 2010 software.

\section{RESULTS AND DISCUSSION}

\subsection{Progress evaluation of microbial growth}

The microbial growth rate in the PVA at the Gel tank was evaluated by the BOD removal efficiency in the first 30 days operation until a stable condition was satisfied, all the experimental conditions were shown in Table 3. In order to have attaching microorganism, the 
$1.6 \mathrm{~m}^{3}$ of AS from the Ha Long WWTP was pumped into the Gel tank; subsequently the PVA particles were added and the BOD removal process was observed at the effluent of the Gel tank during 30 days.

Table 3. Experimental conditions on the evaluation of microbial growth.

\begin{tabular}{lllc}
\hline No. & Parameters & Unit & Values \\
\hline 1 & Capacity load & $\mathrm{m}^{3} / \mathrm{d}$ & 0.8 \\
2 & BOD (input) & $\mathrm{mg} / \mathrm{l}$ & $2500-3000$ \\
3 & BOD loading rate (input) & $\mathrm{kg} / \mathrm{d}$ & 2 \\
4 & Volume of Gel Tank & $\mathrm{m}^{3}$ & 2 \\
5 & BOD loading rate at Gel Tank & $\mathrm{kg} / \mathrm{m}^{3} . \mathrm{d}$ & 1 \\
6 & $\mathrm{pH}$ & & $7.5-7.8$ \\
7 & DO & $\mathrm{mg} / \mathrm{l}$ & $4.5-5.0$ \\
8 & Experimental time & $\mathrm{d}$ & 30 \\
\hline
\end{tabular}

The illustration values in Figure 3 indicated that the adaptation of microorganisms in the PVA particles requires approximately of 30 days. In the first 7 days of experiment, the BOD values at the effluent of the Gel tank were not much changed corresponding to the removal efficiencies of $32-40 \%$. This parameter was dramatically reduced from the initial concentration $(2500-2800 \mathrm{mg} / \mathrm{L})$ to 1600 and $650 \mathrm{mg} / \mathrm{L}$ in the $10^{\text {th }}$ and $25^{\text {th }}$ day of the experiment, respectively. From the $26^{\text {th }}$ to $30^{\text {th }}$ experimental day, BOD values were gradually reduced and reached to the average concentration of $500 \mathrm{mg} / \mathrm{L}$. These results indicated that the adaptations of microorganisms in the PVA particles were clearly marked from the $10^{\text {th }}$ to $25^{\text {th }}$ day in the period of 30 days.

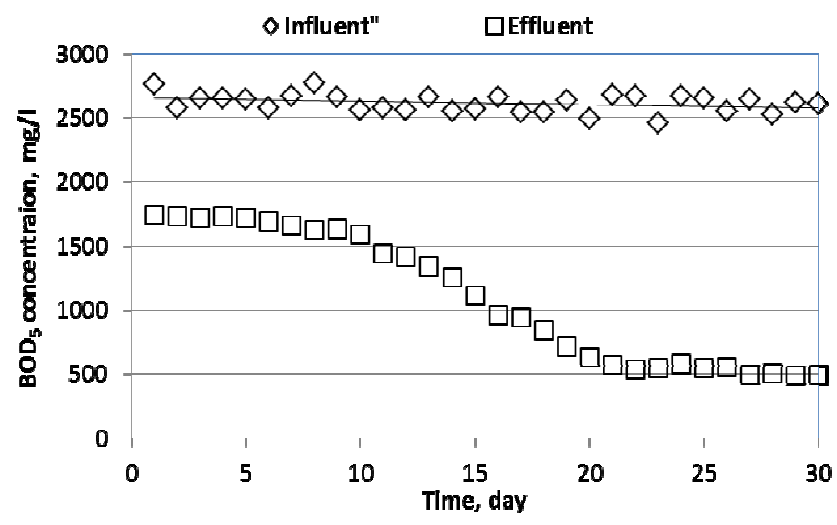

Figure 3. The BOD removal capacity in the start-up operation of the Gel tank.

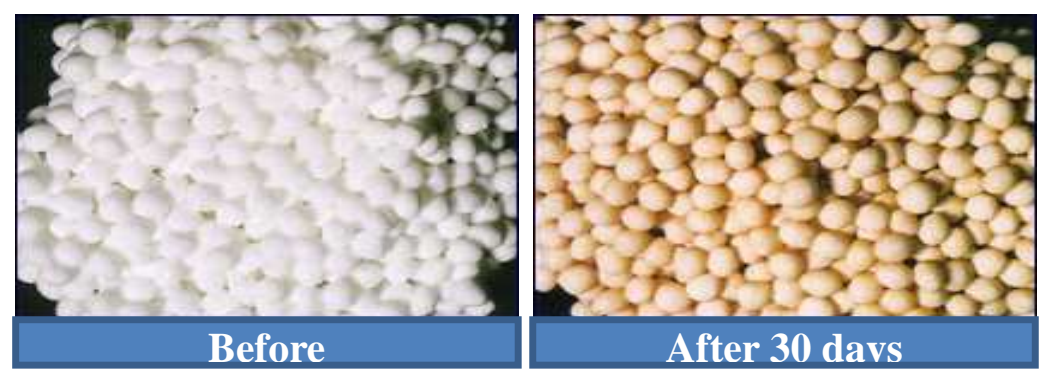

Figure 4. The PVA particles observed before and after 30 days. 
In addition, the difference color between the PVA particles observed before and after 30 days of experiment also improved the presence of microorganisms that had attached in, thus the color was turned from white to yellow brown and particle size was increased by 1.5 times versus the initial (as shown in Fig. 4). The obvious role of microorganism living inside the PVA particles promoted BOD removal efficiency in this pilot. Our results are in good agreement with a previous research by Nguyen Van Loi et al. [8].

\subsection{BOD removal efficiency at the Gel tank.}

As shown in the Fig. 5, the $\mathrm{BOD}_{5}$ concentrations were evaluated at the different $\mathrm{BOD}$ loading rates varied from 1 to $5 \mathrm{~kg} \mathrm{BOD} / \mathrm{m}^{3}$.day. The efficiency of $\mathrm{BOD}_{5}$ removal was quite high when the BOD loading rates varied from $1-2.5 \mathrm{~kg} \mathrm{BOD} / \mathrm{m}^{3}$.day. In this range, the $\mathrm{BOD}_{5}$ effluent values were of about of $500-1000 \mathrm{mg} / \mathrm{L}$ when the $\mathrm{BOD}_{5}$ influent values were from 2500 to $2800 \mathrm{mg} / \mathrm{L}$. However, when the BOD loading was continued increasing up to $5 \mathrm{~kg}$ $\mathrm{BOD}_{5} / \mathrm{m}^{3}$.day, the BOD concentration of Gel tank effluent fluctuated in $1300-1500 \mathrm{mg} / \mathrm{L}$, thus the BOD removal efficiency was decreased. In a previous studies by Le Hoang Viet et al. [9], and Osorio et al. [10], the maximum BOD loading rates were 1.91 and $4.78 \mathrm{~kg} \mathrm{BOD} / \mathrm{m}^{3}$.day, respectively. The relationship between the efficiency of BOD removal and BOD loading rates in the Gel tank was clearly presented in the Fig. 6.

As illustrated in the Fig. 6, when increasing the BOD loading rates from 1 to $2.5 \mathrm{~kg}$ $\mathrm{BOD}_{5} / \mathrm{m}^{3}$.day, the $\mathrm{BOD}_{5}$ removal efficiency of the Gel tank decreased from $80 \%$ to $60 \%$, and maintaining at $50 \%$ when increasing to $5 \mathrm{~kg} \mathrm{BOD} / \mathrm{m}^{3}$.day. These results indicated that the Gel tank was working properly with the BOD loading rates up to $5 \mathrm{~kg} \mathrm{BOD} / \mathrm{m}^{3}$.day.

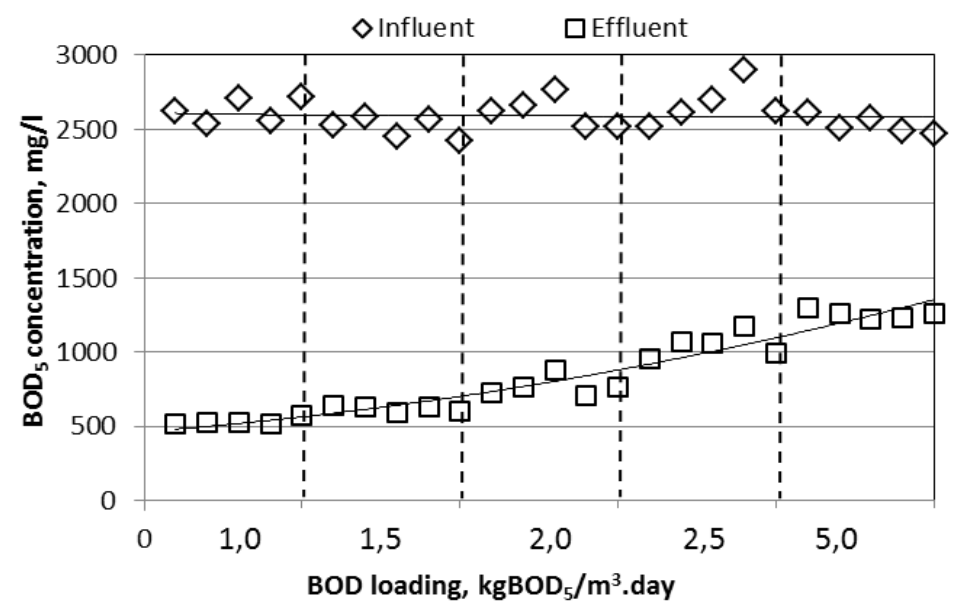

Figure 5. The relationship between the BOD input and output values and BOD loading rates in the Gel tank.

According to Trinh Xuan Lai et al. [11], the maximum loading rates are in the range of $0.32-0.64 \mathrm{~kg} \mathrm{BOD}{ }_{5} / \mathrm{m}^{3}$.day for a regular activated sludge tank (aeroten tank). As the reported of Duong Gia Duc et al., that applied the combination of anaerobic and aerobic process [12], the organic loading rates were also lower than 5 times compared to our results. Based on the achievement data from this work, it could assume that the addition of PVA particles to a regular activated sludge tank such as the aeroten tank of the existed plant in Ha Long WWTP will be able to increase its organic removal loading rate up to 5 times. 


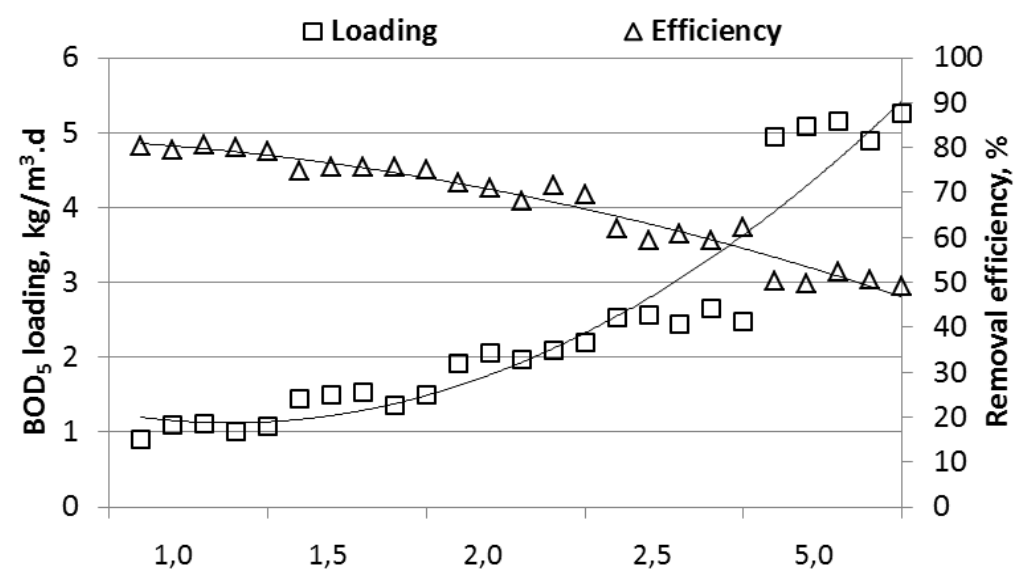

Figure 6. The relationship between the efficiency of BOD removal and BOD loading rates in the Gel tank.

\subsection{The overall BOD removal efficiency of the pilot}

After Gel tank, the WW was pumped to aeroten tank for further treatment. The evaluation of total pilot system's efficiency was presented in the Fig. 7. The combination between Gel tank and aeroten tank is shown a great effect on $\mathrm{BOD}_{5}$ removal.

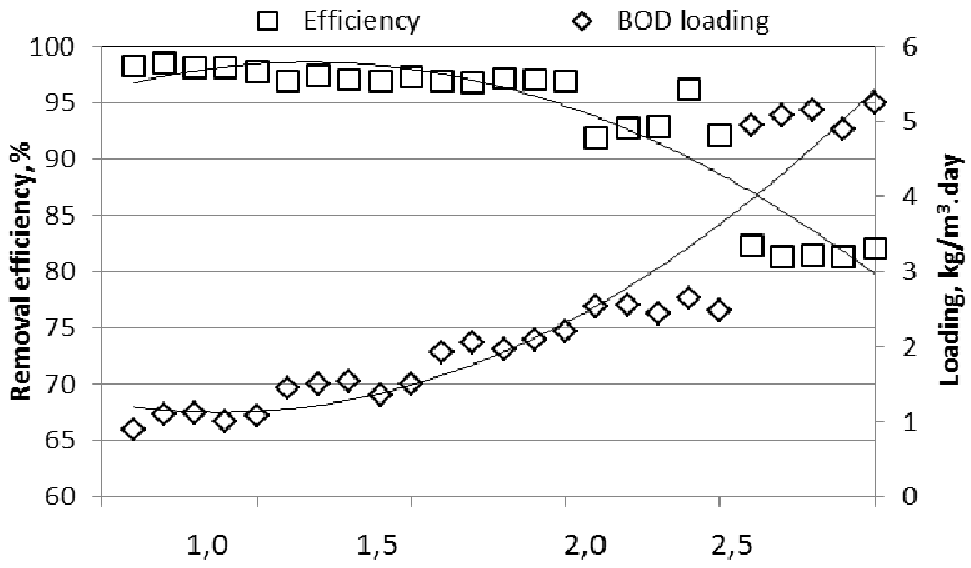

Figure 7. The relationship between the BOD removal efficiency and BOD loading rates in the pilot plant.

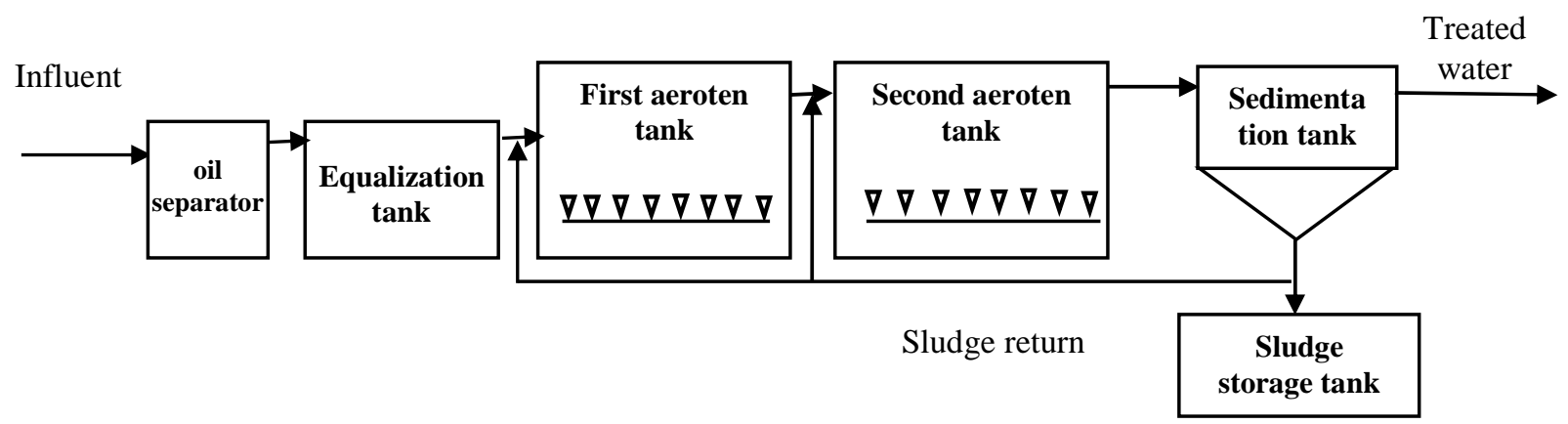

Figure 8. The scheme diagram of WWTP in Ha Long can food company. 
As shown in the Fig. 7, the BOD removal efficiency reached an average value of $95 \%$ when the BOD loading rates ranging from $1-2 \mathrm{~kg} \mathrm{BOD}_{5} / \mathrm{m}^{3}$.day. Increasing the BOD loading rate to 2.5 and $5 \mathrm{~kg} \mathrm{BOD} / \mathrm{m}^{3}$.day, the BOD removal efficiencies were decreased by 10 , and 20 $\%$, corresponding 90 and $80 \%$, respectively. These results indicated that the pilot plant was working properly with the BOD loading rates up to $5 \mathrm{~kg} \mathrm{BOD} / \mathrm{m}^{3}$.day. The efficiency of pilot system was compared to that of existed system in Ha Long WWTP (as shown in Fig. 8). The dramatically differences were observed between the quality of the effluent wastewater in the pilot plant and the existed plant in Ha Long WWTP when BOD loading rate was fixed at $0.7 \mathrm{~kg}$ $\mathrm{BOD}_{5} / \mathrm{m}^{3}$.day as shown in Fig. 9 .

The data collected in 10 days (Fig. 9) indicated the more effective treatment of the pilot plant compared to that of the existed plant in Ha Long WWTP.

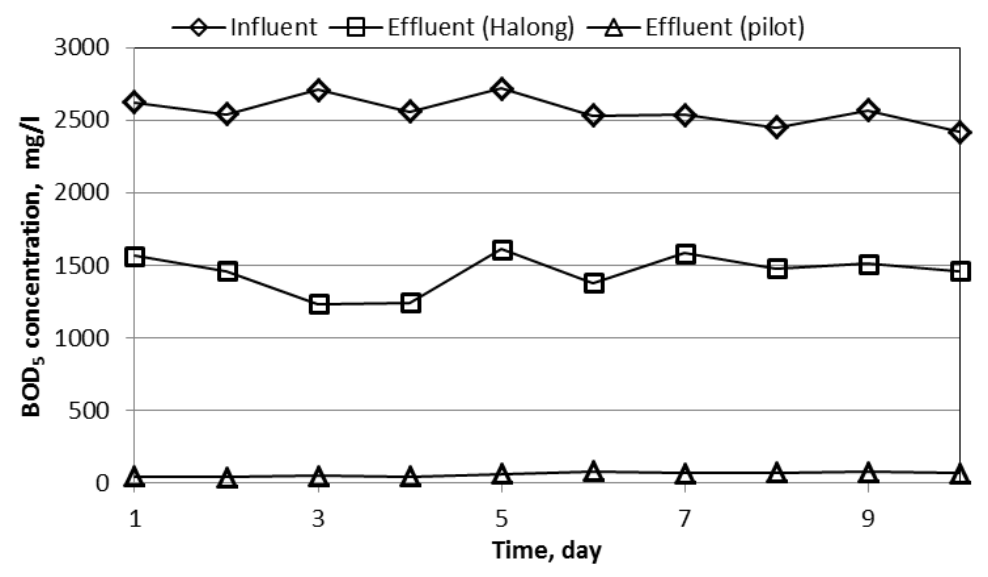

Figure 9. The different BOD removal concentration between pilot plant and the existed Ha Long WWTP.

\section{CONCLUSIONS}

The conducted study deduced the following remarks:

The proper time for microorganism attached inside the PVA particles is around 20 days and stabilization operation system.

The moving bed biofilter technique combined well with conventional activated sludge which was applied for removing of high organic wastewater such as seafood processing. The removal capacity of the system satisfied the BOD loading rates of $2.5 \mathrm{~kg} \mathrm{BOD} / \mathrm{m}^{3}$.day.

Comparing to the conventional activated sludge treatment system of the existed plant in $\mathrm{Ha}$ Long WWTP, the pilot plant has a greater efficiency which is up to $90-95 \%$, whereas that of the two-stages activated sludge system is only $45-50 \%$ removal efficiency.

Based on this achievement, the appropriate suggestion to enhance removal efficiency of conventional activated sludge by implementing moving bed biofilter before aerobic tank.

\section{REFERENCES}

1. Food and Agriculture Organization (FAO) of the United Nations, Fisheries technical paper - 355 Wastewater treatment in the fishery industry, Rome, 1996. 
2. Raquel O. Cristóvão, Cidália M. S. Botelho, Ramiro J. E. Martins, and Rui A. R. Boaventura - Chemical and Biological Treatment of Fish Canning Wastewaters. International J. Bioscience, Biochemistry and Bioinformatics 2 (4) (2012) 237-242.

3. Quang T. V., An H. N., Nam T.V., Thuy P. K. - Assessment of obstacles and proposing solution to improve wastewater management efficience in seafood industrial zone in Da Nang, Da Nang city report, 2015 (in Vietnammese).

4. Ho Chi Minh City Enviromental Protection Agency - Cleaner Production Center. Guidline for cleaner production in the seafood processing industry, Ho Chi Minh City, 2010 (in Vietnamese).

5. Michael K. Stenstrom, Sami Fam and Gary S. Silverman - Analytical methods for quantitative and qualitive determination of hydrocarbon and oil and grease and wastewater, Environmental Technology Letters, Science \& Technology Letters, Vol. Z, 1986, pp. 625-636.

6. Neena Sunny, Lekha Mathai P. - Physicochemical process for fish processing wastewater. Journal of Innovative Research in Science, Engineering and Technology 2 (4) (2013) 901-905.

7. Dai N. V, and Manh D. V. - Assessement of the current sittuation and proposing solution to improve the effectiveness of environmental management in Tho Quang seafood industrial zone, Da Nang, Master thesis in Environmental Science, HaNoi National University, 2015 (in Vietnamese).

8. Loi N. V. - Study on the application of hybrid technology (aerotank) in seafood wastewater treatment in Da Nang, Master thesis, Da Nang University of Science and Technology, 2013 (in Vietnamese).

9. Viet L. H., Ngan N. V. C., Ho T. H., and Phu N. V. - Efficiency of seafood wastewater treatment by submerged aerobic bio-fiter. Journal of Science, CanTho University, Environment and Climate change, 2015, pp. 94-101 (in Vietnamese).

10. Osorio F., Hontoria E. - Wastewater treatment with a double-layer submerged biological aerated filter, using waste materials as biofilm support, Journal of Environnemental Management 65 (2002) 79-84.

11. Lai T. X. - Designing wastewater treatment plants. Construction Publishing House, 2009 (in Vietnamese).

12. Suc D. G. - Study on seafood wastewater treatment by anaerobic (UASB), aerobic (SBR) pilot scale. Reports of the 7th student research in DaNang University, 2010 (in Vietnamese). 